\title{
Bird images in the mosaics of Late Antique basilicas in the town of Sandanski (Blagoevgrad Region, SW Bulgaria)
}

\author{
Zlatozar Boev
}

National Museum of Natural History, Bulgarian Academy of Sciences, 1 Tsar Osvoboditel Blvd, 1000 Sofia, Bulgaria, boev@nmnhs.com, zlatozarboev@gmail.com

\begin{abstract}
This paper presents and analyses for the first time all data on bird images of two Late Antique basilicas of the Roman period $\left(5^{\text {th }}-6^{\text {th }}\right.$ c. AD) in the town of Sandanski (SW Bulgaria). A total of eight species have been recognised on the floor mosaics of both basilicas: Anas platyrhynchos, Bucephala clangula, Dendrocygna viduata, Nettapus coromandelianus, Marmaronetta angustirostris, Porphyrio porphyrio, Psittacula krameri, and Sypheotides indicus. Exotic birds of Palaeotropic (Ethiopian) and Indomalayan (Oriental) distribution confirm once again the active ancient Roman contacts with East and Trans-Saharan Africa and the Hindustan Peninsula.
\end{abstract}

Keywords: ancient art, birds in antiquity, birds-man interrelations, Late Holocene birds, ornithoarchaeology

\section{Introduction}

The town of Sandanski is located in the Petrich-Sandanski kettle and was inhabited from about $2200 \mathrm{BC}$. Its ancient built area was situated within the present territory of the town. Its height in the Antiquity was in $4^{\text {th }}-6^{\text {th }}$ century AD when it was an important Christian centre (Petkov, 2006).

Ancient mosaics of both studied monuments decorated two important Christian temples - the Bishop's Basilica (in the Early Christianity Complex, uncovered in 1967), evaluated as the most valuable building in the town (middle of $4^{\text {th }}$-middle of $6^{\text {th }}$ century) and measured as $22 \mid 36$ m. Its floor mosaics were created in the "Opus tessellatum" and "Opus sektile" style. During that period Sandanski was a main economic and cultural centre in the region. It played an important role in the dissemination of the Christianity.

The second monument, the Basilica of Bishop John, is now located at the area of the present Archaeological Museum of the town of Sandanski (AMS). Its mosaics mostly represent images of fishes and birds and are dated also at $5^{\text {th }}-6^{\text {th }}$ century (Petkov, 2006). The presence of both basilicas was unsuspected until
1917, when the first archaeological finds were excavated during building operations.

Bird images appear in many archaeological monuments excavated throughout the country. The great majority of them remain still unexamined by ornithologists. The most comprehensive study on the place of birds in the everyday life and the art of people in the Thracian and Roman periods was published quite recently (Boev, 2018). It does not deal with the bird mosaics of Sandanski. That is why they are the subject of the present study.

\section{Material and methods}

On 1 June 2018 we visited both monuments in Sandanski and photographed all bird images of the exposed mosaics. The present paper covers only mosaics exposed to the visitors. A small part is still under restoration (Dr Anton Kovachev, director of Archaeological Museum of the town of Sandanski). In our identifications we considered colour features, poses and all general proportions of the body parts of the birds. 

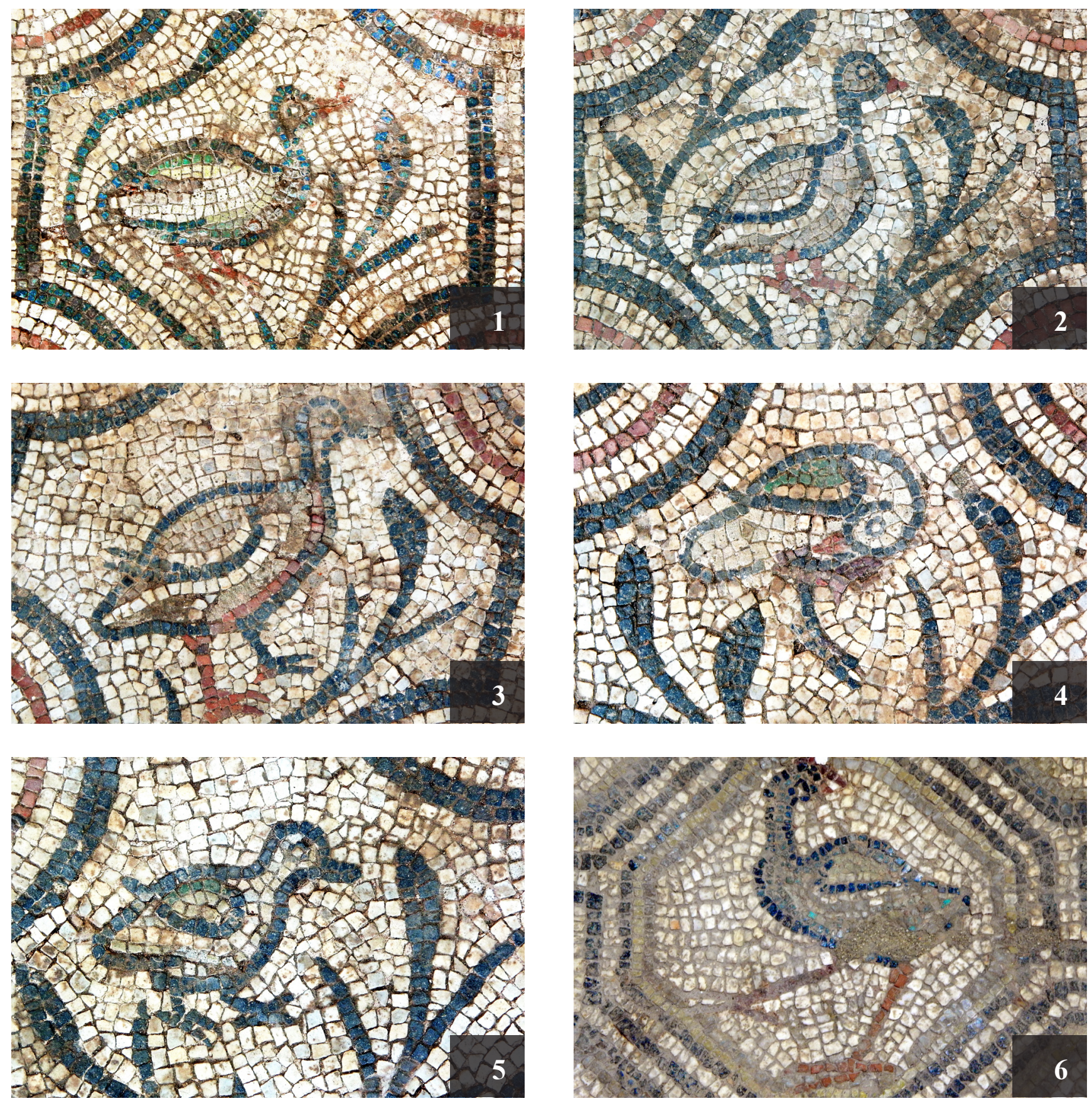

Figs 1-6. Mosaic images of birds from the Roman basilicas in the town of Sandanski: (1) Anas platyrhynchos, (2) Bucephala clangula, (3) Dendrocygna viduata, (4) Nettapus coromandelianus, (5) Marmaronetta angustirostris, (6) Porphyrio porphyrio.

\section{Results and discussion}

We established at least eight species of recent birds in the Roman mosaics. In the floor stone mosaics the most numerous were: Porphyrio porphyrio (8 images), Psittacula krameri (8 images) and Anas platy- rhynchos (8 images), Nettapus coromandelianus (2 images), etc. Most of the recognised species have natural Palaearctic distribution but some of them represent exotic (Palaeotropic (Ethiopian) and Indomalayan (Oriental)) or vagrant for the Balkans visitors (Figs 1-8). These birds belong to six orders: Anseri- 
Bird images in the mosaics of Late Antique basilicas in the town of Sandanski (Blagoevgrad Region, SW Bulgaria)
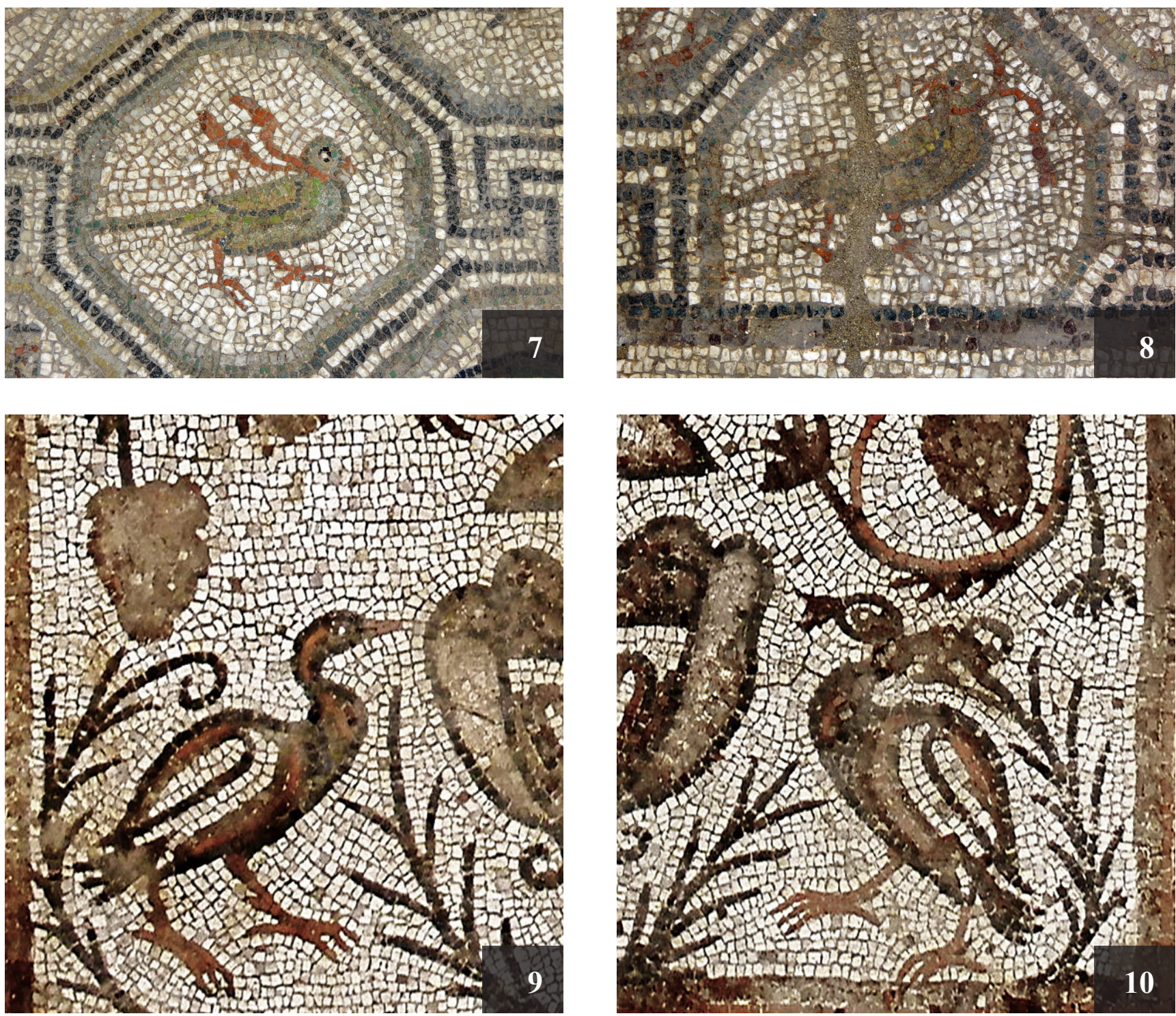

Figs 7-10. Mosaic images of birds from the Roman basilicas in the town of Sandanski: (7) Psittacula krameri, (8) same, (9) Sypheotides indicus, (10) same.

formes (5 species - mallard (Anas platyrhynchos), common goldeneye (Bucephala clangula), whitefaced whistling-duck (Dendrocygna viduata), cotton pygmy-goose (Nettapus coromandelianus), marbled teal (Marmaronetta angustirostris)), Otidiformes (1 species - lesser florican (Sypheotides indicus)), Gruiformes (1 species - purple swamphen (Porphyrio porphyrio)), and Psittaciformes (1 species - rose-ringed parakeet (Psittacula krameri)).

At present, only three species (Anas platyrhynchos, Bucephala clangula and Marmaronetta angustirostris) are part of the recent avifauna of Bulgaria (Ivanov et al., 2009, 2015). Psittacula krameri is con- sidered as potentially invasive species and has penetrated in Bulgaria even over the last two decades (Grozdanov et al., 2017). Anas platyrhynchos and $M$. angustirostris are recorded in Bulgaria, the first species as a common breeder, the second as an extremely rare bird with unknown status (Nankinov et al., 1997). The mallard's distribution (Fig. 11) covers most of Europe, Asia and North America, and reaches even Tasmania and New Zealand (Carboneras, 1992). Marmaronetta angustirostris has sporadic Palaearctic distribution (Fig. 12), from Spain and North Africa through the Middle East and South-west Asia and China. The species is dispersive and partially migra- 


\section{Zlatozar Boev}

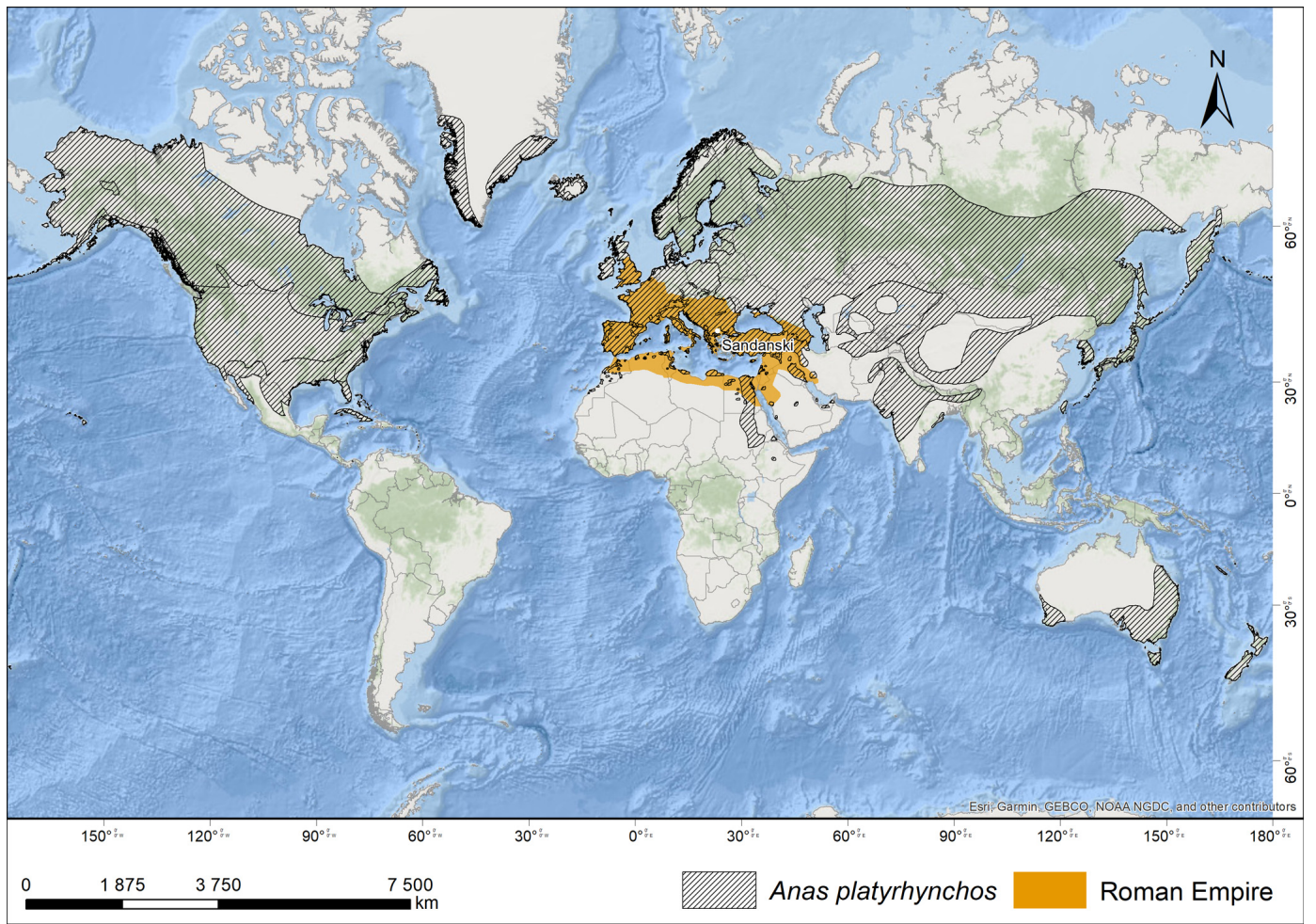

Fig. 11. Present range of mallard (Anas platyrhynchos) and the territory of the Roman Empire at the time of its height in 117 AD. (After BirdLife International and Handbook of the Birds of the World, 2017).

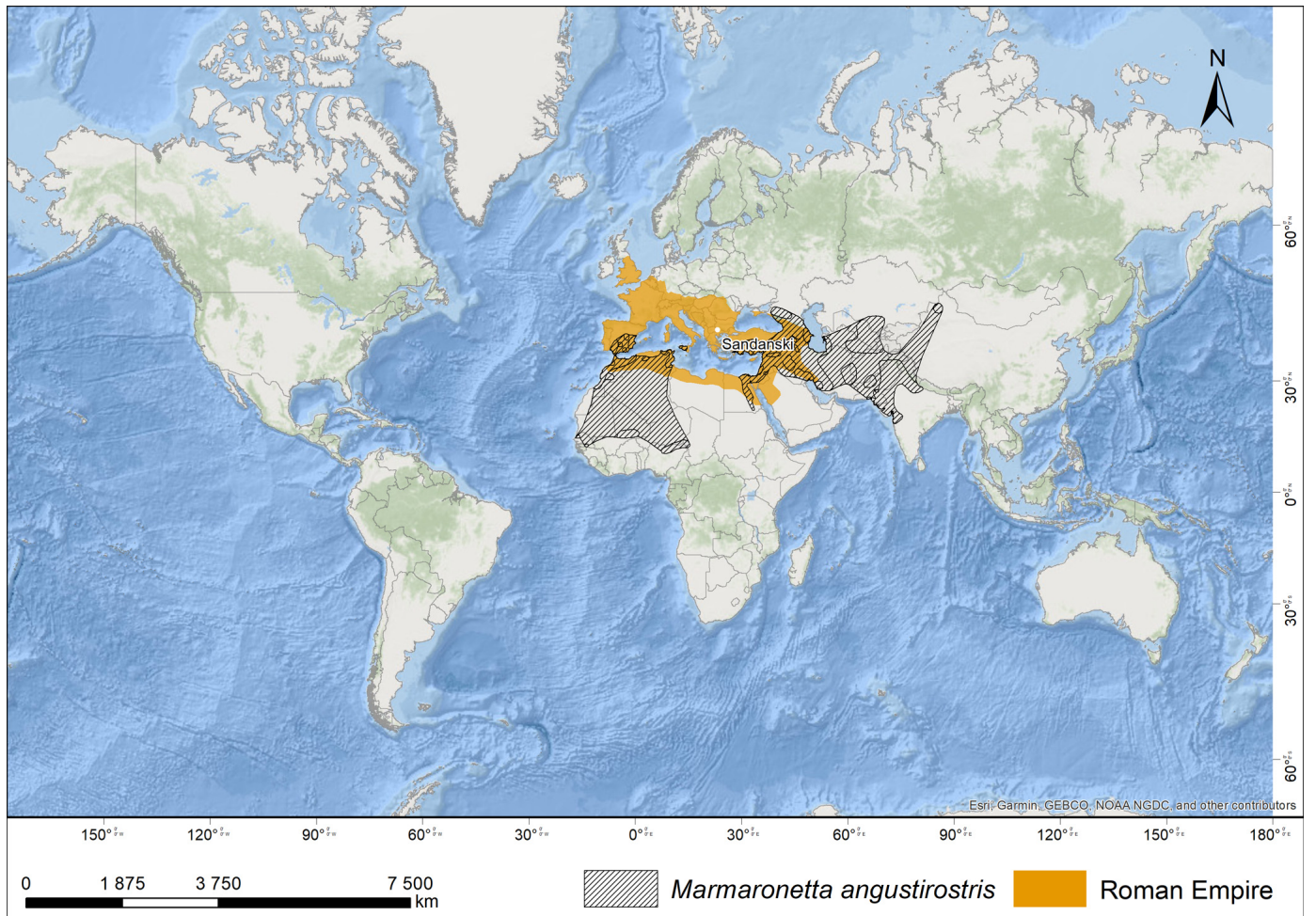

Fig. 12. Present range of marbled duck (Marmaronetta angustirostris) and the territory of the Roman Empire at the time of its height in 117 AD. (After BirdLife International and Handbook of the Birds of the World, 2017). 
Bird images in the mosaics of Late Antique basilicas in the town of Sandanski (Blagoevgrad Region, SW Bulgaria)

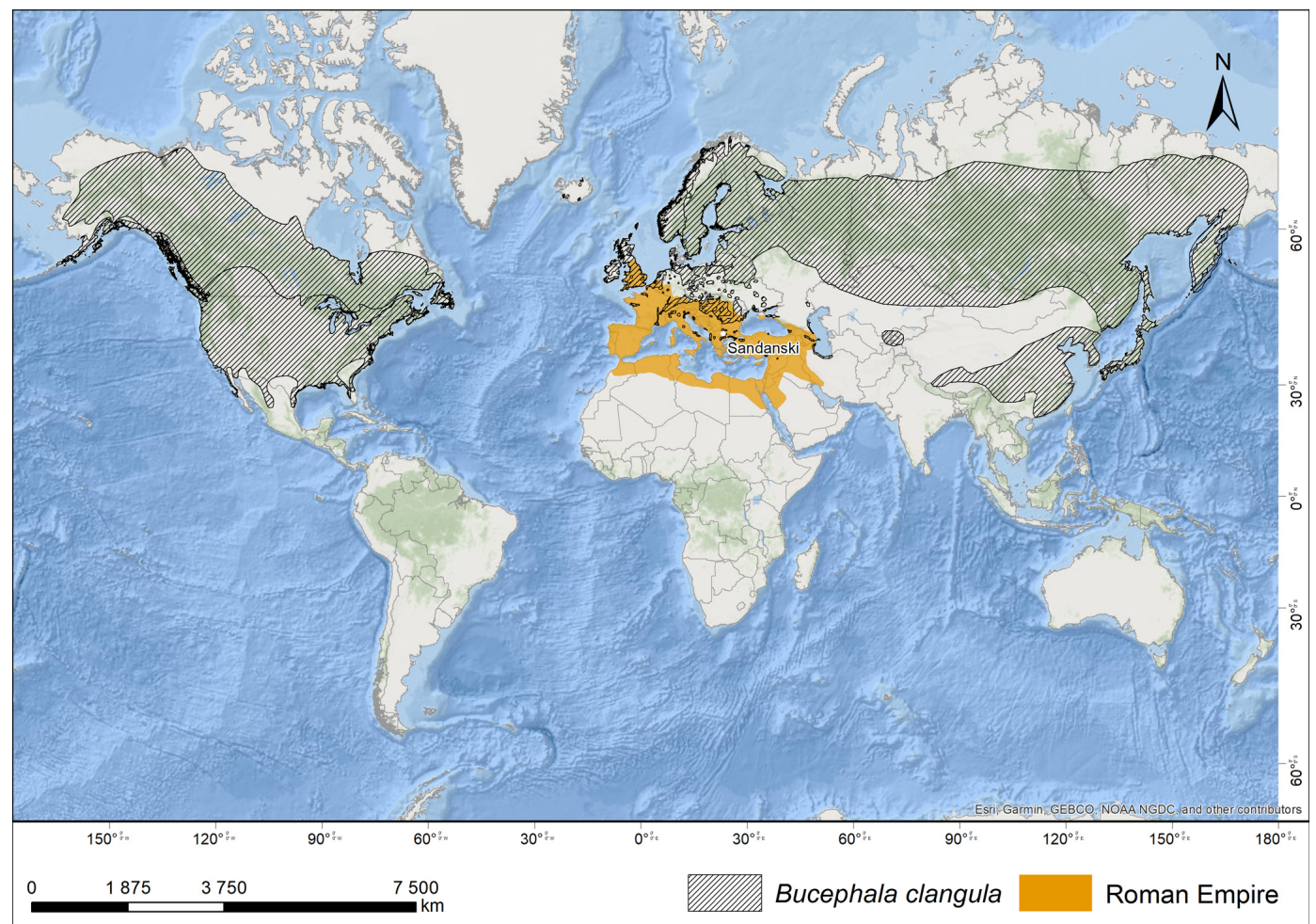

Fig. 13. Present range of common goldeneye (Bucephala clangula) and the territory of the Roman Empire at the time of its height in 117 AD. (After BirdLife International and Handbook of the Birds of the World, 2017).

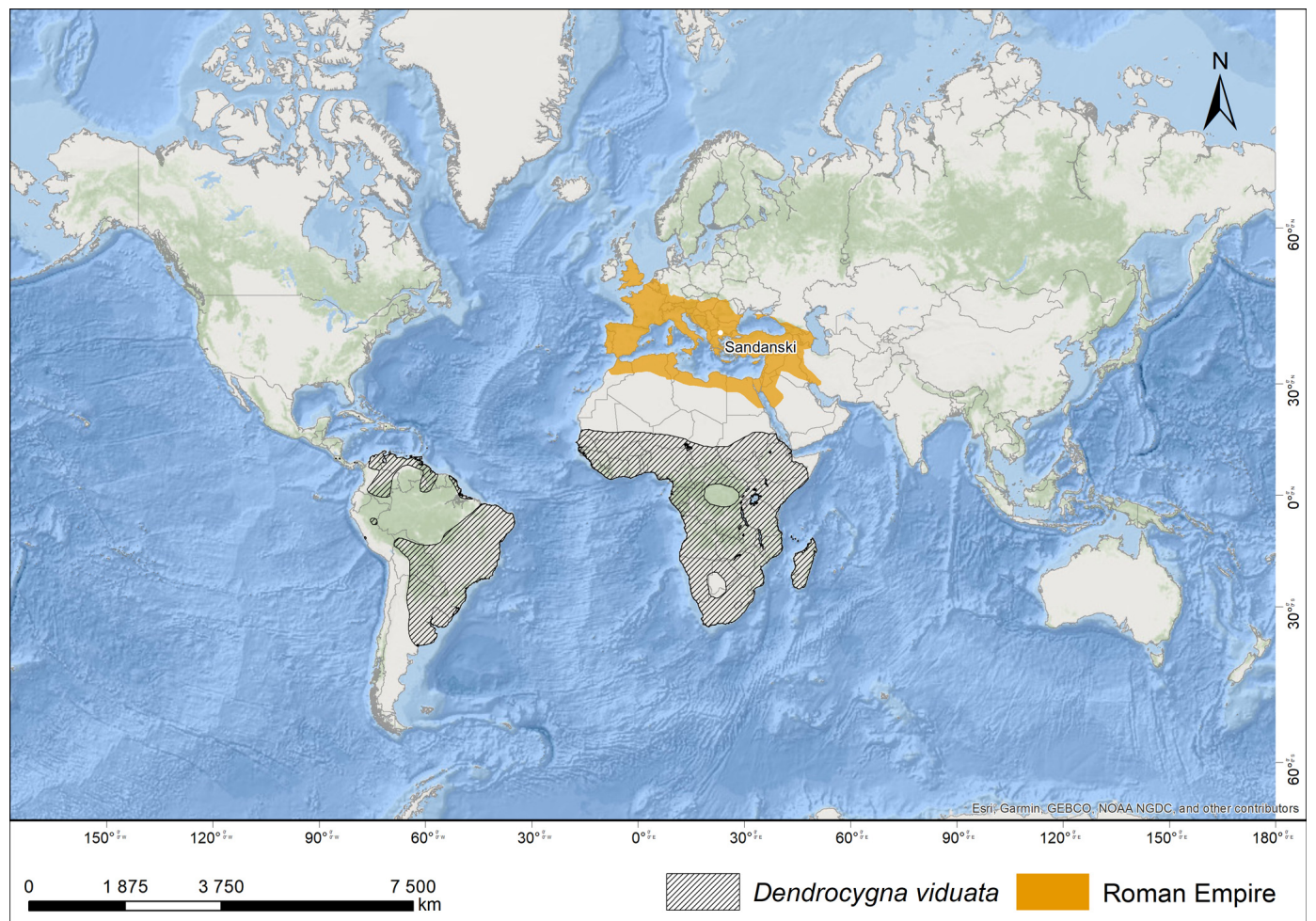

Fig. 14. Present range of white-faced whistling duck (Dendrocygna viduata) and the territory of the Roman Empire at the time of its height in 117 AD. (After BirdLife International and Handbook of the Birds of the World, 2017). 


\section{Zlatozar Boev}

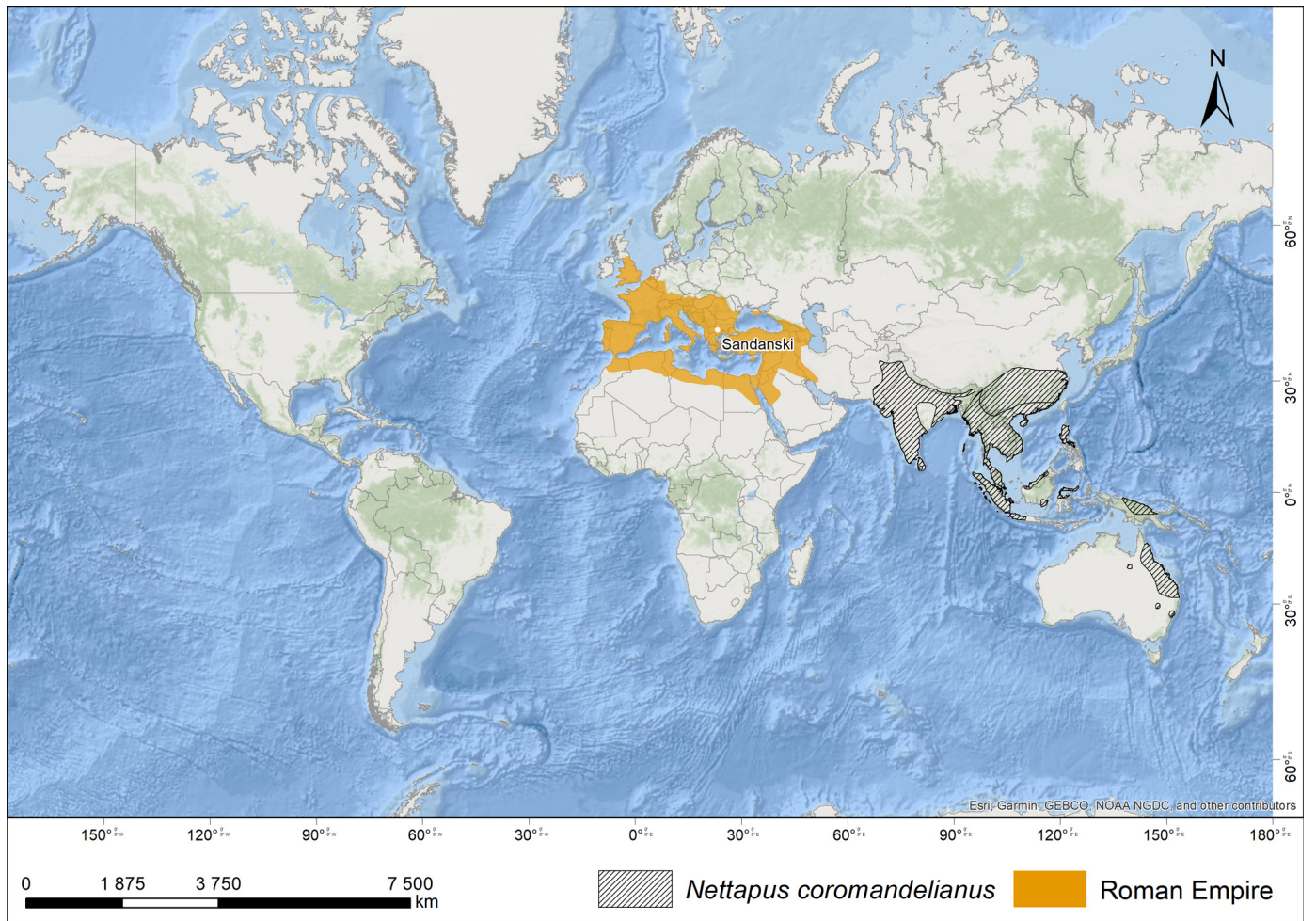

Fig. 15. Present range of cotton pygmy goose (Nettapus coromandelianus) and the territory of the Roman Empire at the time of its height in 117 AD. (After BirdLife International and Handbook of the Birds of the World, 2017).

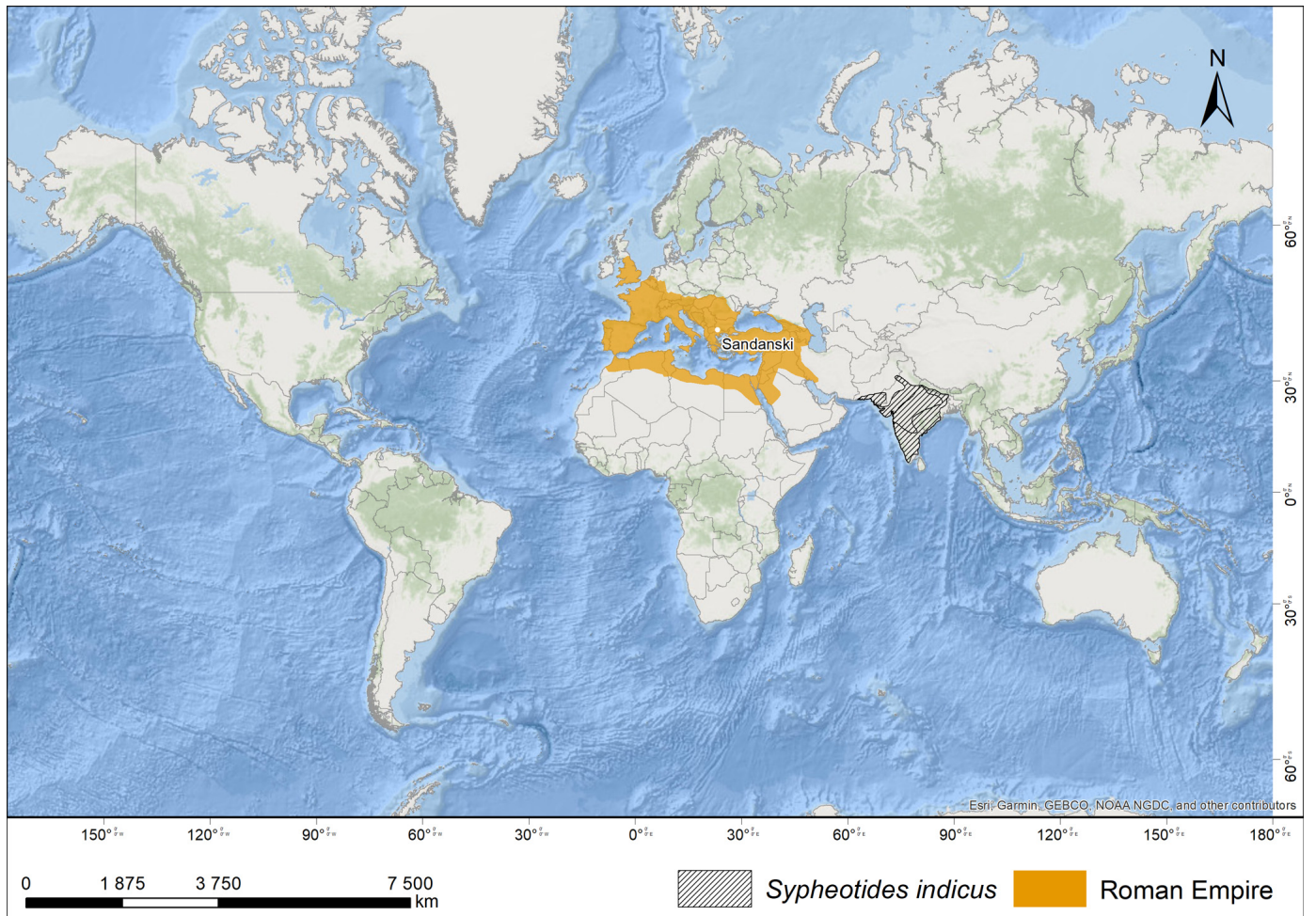

Fig. 16. Present range of lesser Florican (Sypheotides indicus) and the territory of the Roman Empire at the time of its height in 117 AD. (After BirdLife International and Handbook of the Birds of the World, 2017). 
Bird images in the mosaics of Late Antique basilicas in the town of Sandanski (Blagoevgrad Region, SW Bulgaria)

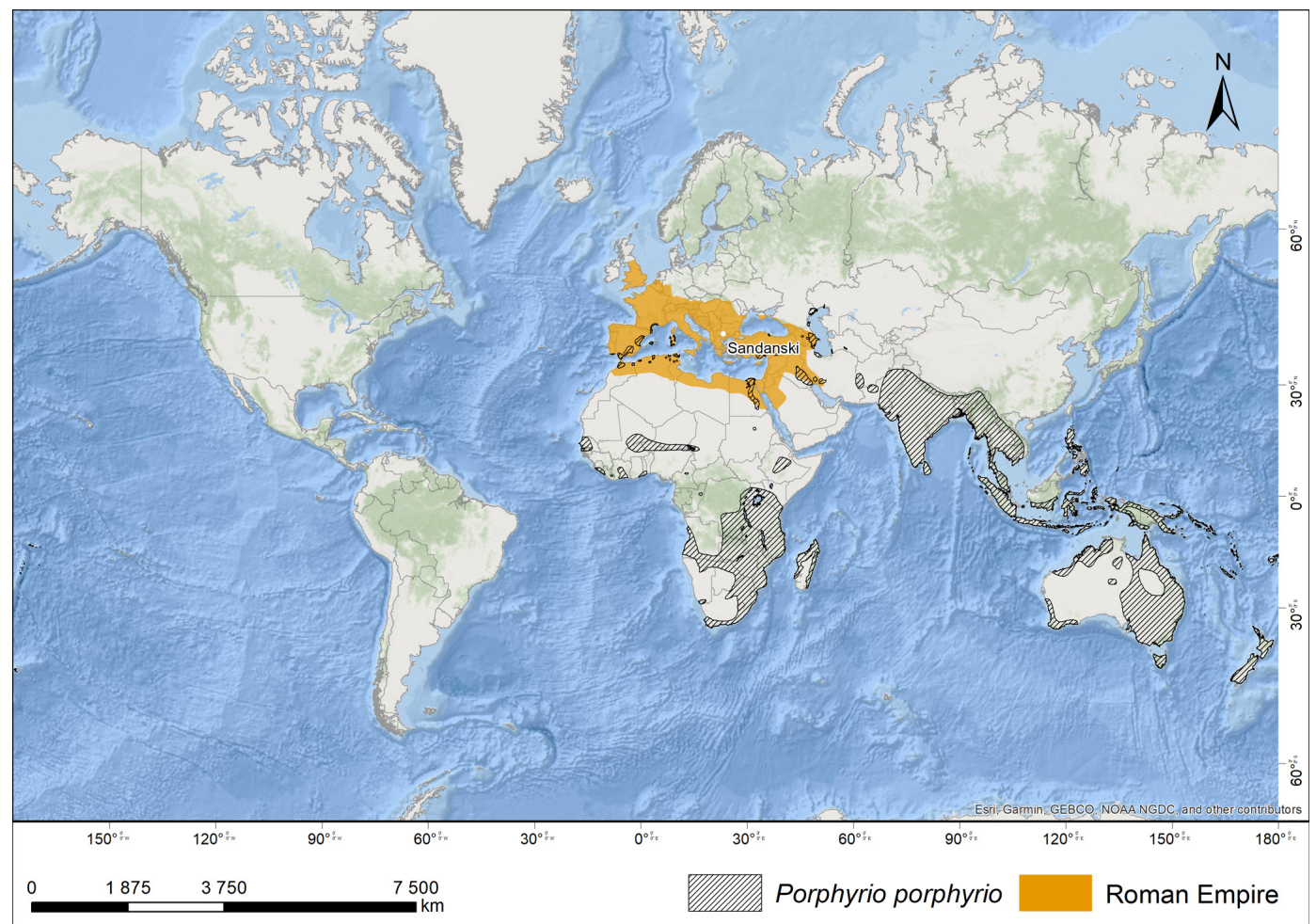

Fig. 17. Present range of western swamphen (Porphyrio porphyrio) and the territory of the Roman Empire at the time of its height in 117 AD. (After BirdLife International and Handbook of the Birds of the World, 2017).

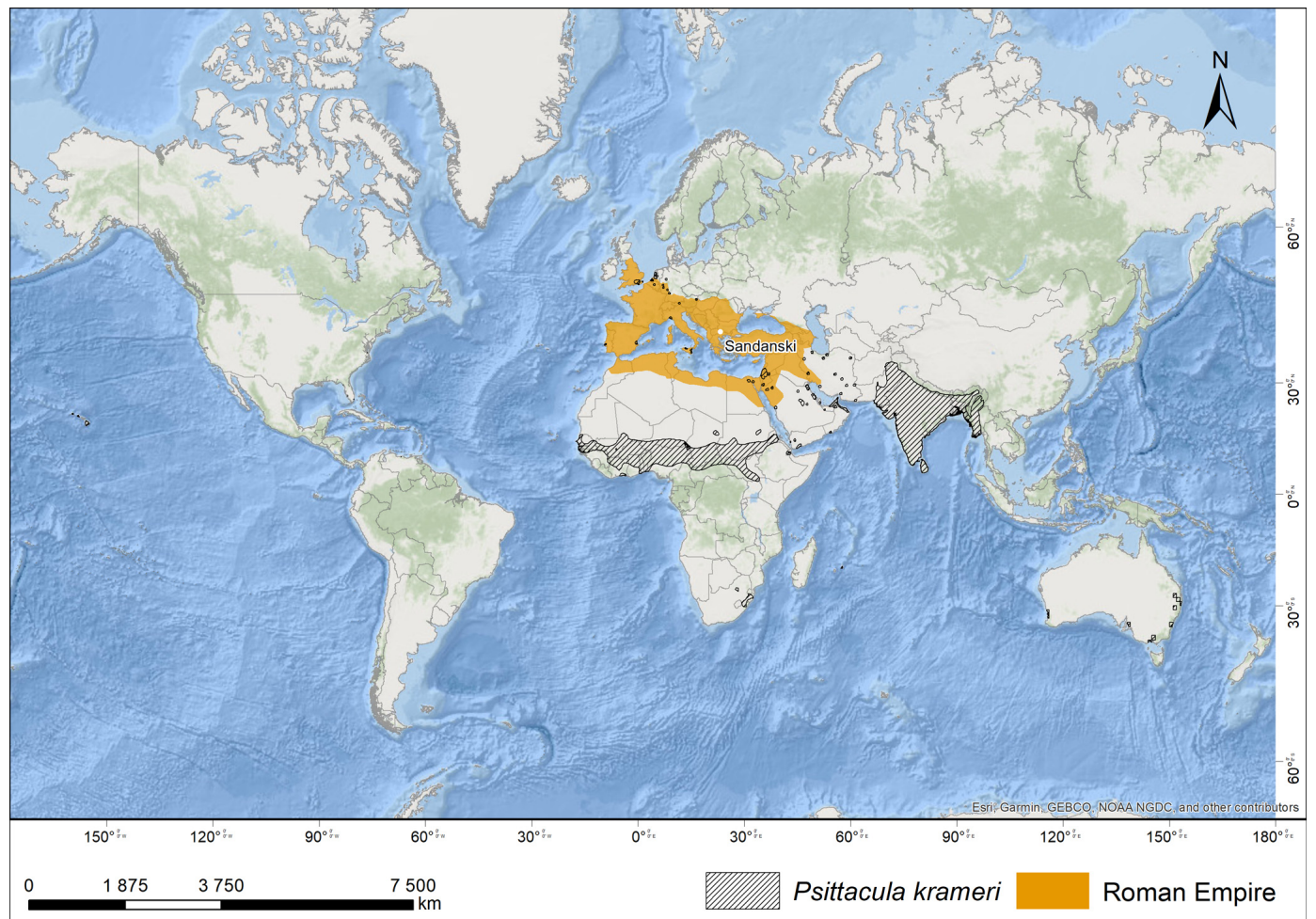

Fig. 18. Present range of rose-ringed parakeet (Psittacula krameri) and the territory of the Roman Empire at the time of its height in 117 AD. (After BirdLife International and Handbook of the Birds of the World, 2017). 
tory (Carboneras, 1992). Bucephala clangula is widely spread anatid with Holarctic distribution (Fig. 13). At present, the species breeds out of the regions of the former Roman Empire, but some populations winter in the Mediterranean (Carboneras, 1992).

Dendrocygna viduata is a resident widely spread duck in the Paleotropic and Neotropic regions (Fig. 14). It inhabits all Sub-Saharan Africa (Carboneras, 1992).

Nettapus coromandelianus is widely spread in Hindustan and Indochina (Fig. 15) but the Northern East-Asian populations make long-distance south migrations and winter in East Australia (Carboneras, 1992). Sypheotides indicus is mainly a resident species. It breeds and winters mainly in the Hindustan Peninsula (Fig. 16). In summer rarely reaches Nepal (Collar, 1996). Porphyrio porphyrio is a resident species spread from SW Europe (Fig. 17) to Australia, South Africa and New Zealand (Taylor, 1992). Its mosaic images are known in many Bulgarian Roman towns, villas, etc. (Boev, 2018). Psittacula krameri is spread in the Sub-Saharan Africa, north of the equator, in the Near East and Hindustan (Fig. 18). Elsewhere it is a resident species (Collar, 1997). The images of these parrots are also present in the Bishop basilica in the ancient Philipopolis (Boev, 2018).

The Roman-Hindustan contacts and trade are well known (Smith, 1908, Miller \& Innes, 1969). Moreover, the trade of exotic animals of other continents was indicative for the wealth of their owners. Many Roman (i.e. European!) owners of villas decorated their floors with picturesque mosaics of animals from Africa, India, even Indonesia.

The hunting or decorative animals are represented in such detail that it is possible to identify the species. In some Roman villas in Italy Indian rhinoceroses, Indian elephants, Indian peafowl and tigers can be seen. All these (and many other) animals were transported to Europe in cages by ship.

\section{Conclusions}

Although, no ornithoarchaeological evidences have been obtained so far in Bulgaria for the confirmation of the former presence of individuals of these exotic Afrotropical and Indomalayan birds, their high informative mosaic images in the Bulgarian ancient monuments support the importation of these birds as live specimens in the ancient Bulgarian lands during the
Roman period. They also elucidate the importation of decorative exotic birds by the Romans along with the large animals as ostriches, Indian rhinoceroses, big felids (lions, leopards and tigers), etc. On the other hand, we know that "the images on floor mosaics in early Christian temples throughout the Eastern Mediterranean and the Balkan Peninsula, in particular, are symbolically loaded and standardised, strictly subject to liturgical requirements. Styling analyses of numerous monuments from this period clearly demonstrate the existence of common templates and patterns used by mosaic masters in different parts of the ancient world" (Dr Veselka Katsarova, National Archaeological Institute and Museum, pers. comm.). Having in mind the scope of the Roman Empire, we cannot exclude any of these two possibilities.

\section{Acknowledgements}

The author thanks to Dr Anton Kovachev, director of the AMS, who permitted taking close photographs from the mosaics. I am also grateful to Prof. Vasil Nikolov (National Archaeological Institute and Museum, Bulgarian Academy of Sciences, NMNHS), who evaluated as promising the present study as a part of the multidisciplinary project: "Thracians - Genesis and Ethnic Development, Cultural Identities, Civilisation Interactions and Heritage of Antiquity" of the Bulgarian Academy of Sciences. Special thanks to Georgi Popgeorgiev (NMNHS) for preparing the distribution maps of birds. BirdLife International provided distribution maps of some exotic birds.

\section{References}

BirdLife International and Handbook of the Birds of the World 2017 Bird species distribution maps of the world. Version 7.0. http://datazone.birdlife. org/species/requestdis.

Boev Z. 2018 Birds in everyday life and art in Bulgaria (Thracian and Roman periods). Historia naturalis bulgarica 25: 3-39.

Carboneras C. 1992 Family Anatidae (Ducks, geese and swans). In: del Hoyo J., Elliott A., Sargatal J. (eds) Handbook of the Birds of the World. Vol. 1. Lynx Edicions, Barcelona. 536-630.

Collar N. 1996 Family Otididae (Bustards). In: del Hoyo J., Elliott A., Sargatal J. (eds) Handbook of 
the Birds of the World. Vol. 3. Hoatzin to Auks. Lynx Edicions, Barcelona 240-275.

Collar N. 1997 Family Psittacidae (Parrots). In: del Hoyo J., Elliott A., Sargatal J. (eds) Handbook of the Birds of the World. Vol. 4. Sandgrause to Cuckoos. Lynx Edicions, Barcelona 280-479.

Grozdanov A., Popova E., Peev S. 2017 New Records of the Rose-ringed Parakeet Psittacula krameri (Scopoli, 1769) (Aves: Psittacidae) in Bulgaria. Acta zoologica bulgarica Suppl. 9: 305-307.

Ivanov B., Iankov P., Boev Z., Georgiev D., Profirov L., Dimitrov M. 2015 List of the birds recorded in Bulgaria (Bulgarian List). http://www.bunarco. org/bg/dokladi.html.

Ivanov B., Iankov P., Boev Z., Georgiev D., Profirov L., Dimitrov M. 2009 List of the Birds Recorded in Bulgaria. Acta zoologica bulgarica 61 (1): 3-26.

Miller J. 1969 The Spice Trade of The Roman Empire: 29 B. C. to 641 A. D. Special edition for
Sandpiper Books. Oxford at the Clarendon Press, Oxford, $294 \mathrm{pp}$.

Nankinov D., Simeonov S., Ivanov B. 1997 Fauna of Bulgaria. Vol. 26. Aves - Part 3. Professor Marin Drinov Academc of Publishing House, Pensoft Publishers, Sofia, 427 pp. (In Bulgarian)

Petkov V. 2006 Istoriya na arheologicheskite prouchvaniya v grad Sandanski (1917-2002). In: Milcheva A., Katsarova V. (eds). Spartacus II. Faber. Veliko Tarnovo 240-245. (In Bulgarian)

Smith V. 1908 The Early History of India: From 600 B. C. to the Muhammadan Conquest including the invasion of Alexander the Great. Oxford at the Clarendon Press, Oxford, 512 pp.

Taylor P. 1992. Family Rallidae (Rails, gallinules and coots). In: del Hoyo J., Elliott A., Sargatal J. (eds) Handbook of the Birds of the World. Vol. 1. Lynx Edicions, Barcelona, 108-209. 